\title{
ETHICS AND AESTHETICS IN THE SONG OF SONGS
}

\author{
Mark W. Elliott
}

\section{Summary}

While readings of the Song of Songs tend to focus on the extent of its licencing of pre-marital sex, the Song's message on the nature of sexual and human loving is to be found in its choice of metaphors for that activity. These, while not revealing the divine nature, direct the readers' gazes towards heavenly love (in the Christian tradition, He is 'seated at the right hand of the Father') so as to be better able to hear revealed instructions for loving.

Our almost-instinct almost true:

What will survive of us is love.

(Philip Larkin, An Arundel Tomb)

Discussions of the relationship of the Song of Songs to contemporary sexual ethics in scholarly works varies according to country and religious climate. So in Britain, an Old Testament scholar can take a New Testament scholar to task for equating 'trial' sexual relationships before marriage (as depicted by the Song) with the Hebrew Biblical institution of betrothal. ${ }^{1}$ It seems tacitly agreed by both parties that there are boundaries around sexual freedom which the Bible is involved in the process either of shifting or defending. In France the massive work of A.-Marie Pelletier on the Song hardly deigns

${ }^{1}$ See A.E. Harvey, 'Marriage, Sex and the Bible', Parts I and II, Theology 129 (1993) 364-372 and 461-468, and the response of R.W.L. Moberly, Letter to the Editor, Theology 130 (1994) 40-41. 
to deal with such an issue; ${ }^{2}$ one senses that after Raymond Tournay's abandonment of his rearguard defence of the Christian allegorical interpretation, ${ }^{3}$ the alternatives left are to read it as proclaiming the covenant love of the Jewish God or as expressing human aspirations of an existential nature. Meanwhile in the German-speaking world, Kurt Lüthi follows in the way established by Helmut Gollwitzer as long ago as the 1977 Kirchentag to the effect that the Song provides no message of discrimination or 'ruling out'. ${ }^{4}$ A strong sense that young Lutherans still need to step out of chains and inhibitions already broken pervades the discourse.

In Western scholarship on the Song, a universalising and personalising of the motifs of the Song according to psychoanalytic categories combines with the now established trend which sees a text like the Song as a prime candidate for 'reader-response' criticism. This movement holds that preoccupation with authorial or 'historical' meaning or even 'canonical context' is superfluous, and despite a more mature approach which places the emphasis on 'intersubjectivity' (in which the meaning is the amalgam of plural subjective responses), any interpretation still begins with the reader. The ethical 'precipitate' of such theories has been, largely, that the Song celebrates sexual love (aside from marriage) and declares this love to contain its own wisdom for a couple's guidance. ${ }^{5}$

The above analysis leaves the more 'traditional' Christian reader with two alternatives. One is to reaffirm that the Song teaches the goodness of sex as given in prelapsarian creation and that it counsels patient stewardship of such a bonum, insisting that marriage comes 'before' sex temporally and ontologically. 6 The other is to admit, with a large sector of

${ }^{2}$ Lectures $d u$ Cantique des Cantiques (Roma: Editrice Pontificio Istituto Biblica, 1989).

${ }^{3} Q$ uand Dieu parle aux hommes le language de l'Amour (Paris: Gabalda, 1983).

${ }^{4}$ 'Das Hohe Lied der Bibel und seine Impulse für eine heutige Ethik der Geschlechter', Theologische Zeitschrift 49 (1993) 97-114; later published as Das hohe Lied der Liebe (München: Kaiser Traktate, 1978).

${ }^{5} \mathrm{Cf}$. Gollwitzer, Das Hohe Lied, 35, '... die Erkenntnis, ich werde nur glücklich durch das Glück des anderen, ist die Weisheit des Eros'.

6See the helpful article by B.G. Webb, 'The Song of Songs: A Love Poem and as Holy Scripture', Reformed Theological Review 49 (1990) 91-99. 
the Christian tradition that sex is not essentially good at all, 7 and starts from a neutral position, and then to go on to say that while the ethic of chastity outside marriage may be valid for its own reasons, its content is not the contribution of the Song of Songs. Rather, the Song teaches the necessity of reflection on sexual feelings; but also that their interpretation by a particular aesthetic is the presupposition for handling these feelings in a fruitfully ethical way. In what follows I shall deal with the subject of aesthetics as crucial for modern interpretations of the Song, examine the relationship between divine and human love as witnessed to by this book of Scripture, and conclude with the ethical implications of understanding the biblical aesthetic.

\section{Aesthetics in the Song}

\section{i. Human Love as Reflecting Divine Love.}

In asking about aesthetics we are asking what is seen or to be seen by the reader in a given text, particularly those things which are 'eye-catching' precisely because they reflect a more hidden truth.

It has become fashionable in dark days to affirm in creation what can be most easily affirmed. Thus Paul Ricoeur disdains the pessimistic world-view of Heidegger and affirms that humanity is not so much bounded by mortality but by eternity. ${ }^{8}$ Such a prescription for authentic human existence is reflected in modern understandings of the Song. An influential recent work by Francis Landy 9 views the Song as balanced on two fulcra, namely the sleep after the love-making of Song 5:1 which ends in the 'morning' awakening of 5:2 and the

7Thus Bernard of Clairvaux, whose high view of the body, according to A.E. Matter, The Voice of My Beloved. (Philadelphia: University of Pennsylvania Press, 1990) 140f., was a result of his struggles with Cathar spiritualists. P. Brown, in The Body and Society (New York: University of Columbia Press, 1988) ch. 19, argues that even Augustine saw the body as neutral no-man's land between God and the distorted human will.

${ }^{8}$ See K. Vanhoozer, Biblical Narrative in the Philosophy of Paul Ricoeur (Cambridge: Cambridge University Press, 1990) ch. 1.

${ }^{9}$ Paradoxes of Paradise: Identity and Difference in the Song of Songs (Sheffield: Almond Press, 1983). 
corresponding climax in 8:6 where love is said to overcome death. ${ }^{10}$ In Landy's analysis, it is as if from chapter 5 onwards the book builds on the depiction of human love in the first four chapters, in order to consider divine love in which the cosmos is united and even chaos is redeemed. It is through the full materiality of the former we arrive, with the Song, at the latter. Although the claim of a bipartite structure which Landy makes for the Song is not convincing, his suggestion that it has more than merely human sexual love in view is worth pursuing.

Landy is optimistic about the possibilities concerning human love which the Song declares. Ultimately what is said in 8:6 must have cash value in human terms: 'If it is to be better than wine, it must promise more than forgetfulness' ${ }^{11}$ Human love, he thinks, is reinforced with divine love; the latter as eros has a good pedigree not only in the Neoplatonic but also in the biblical tradition. ${ }^{12} \mathrm{He}$ alerts us to the God of Israel's marital long-suffering in Hosea, his forbearance in the prophets at large, the recurrent tenderness. In a similar way 'the burning bush' (Ex. 3:2ff.) is conceptually cognate with the term in Song

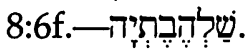

\section{ii Counter-thesis: the Song without the Divine}

Such a close kinship between divine and human love as operating in the Song has, however, been disputed by other recent work in this field. That comedy may be used to undermine the idolatry that takes sex so seriously as to give it a place in a religious cult is a theme discussed by Athalya Brenner. In her 1990 article she claims masculine ribaldry in the face of sex is exposed by the female author; ${ }^{13}$ in a comic yet

10 Paradoxes, 51.

11 paradoxes, 123.

${ }^{12}$ 'The erotic drive is the divine flame, through which the world continues in being; the lovers, in whom all the creatures are united, through creating new life, perpetuate his work' (Paradoxes, 127). These sentiments recall the synergistic ideas of Process Theology as well as the cosmic theology of Teilhard de Chardin.

13"“Come back, come back the Shulammite" (Song of Songs 7.1-10): A Parody of the Wasf Genre', in Y.T. Radday \& A. Brenner (eds.), On Humour and the Comic in the Hebrew Bible (Sheffield: Sheffield Academic Press, 1990) 251-76. 
painful way description of the woman in the standard Ancient Oriental form of the wasf presents her as seen through the male gaze or leer. ${ }^{14}$ By 1993, due largely to an informed scepticism about finding the objective 'structure of composition', she holds that it is permissible to let the text speak to, and in that sense be shaped by, the reader's own experiences, but also that it must be allowed to address the theme of its own subject-matter-human sexuality; so, rampant subjectivity of interpretation is controlled. 15

In both her contributions, the Song, for Brenner, is not about God. Where women are active God becomes absent, his authority and that of his male representatives effete and ineffectual. 16 The Song totally subverts any notion that its own text could be understood as giving clues about the mystical 'body of God'; the only wasf about the male (5:10-16) is a parody (it describes a statue), and even if those in chapters 4 and 7 are to be taken as highly serious it is a female body they describe. Nor can a path be followed from the idea of 'otherness' in the Song as suggestive of divinity lurking behind 'femaleness': the military imagery used in the description of women $(4: 4 ; 6: 10)$ is more a reflex of male fear and powerlessness in the private domain than a symbol signifying something religious or cosmic. Ultimately Brenner wants to remove the Song from the Jewish hermeneutical grid which regards its message as something deep and meaningful. 17 If for Phyllis Trible it was about equality and mutuality, 18 for the feminist of the $90 \mathrm{~s}$ its message is one of female dominance.

\footnotetext{
14Presumably, as a female account of a male perspective, it represents a kind of inversion of the Molly Bloom soliloquy at the close of Joyce's Ulysses.

${ }^{15}$ 'Whose Love is celebrated in the Song of Songs?', Biblical Interpretation 1 (1993) 265-84.

16Thus reference is made ('Whose Love?', 273) to Deborah and Esther.

${ }^{17}$ 'Whose Love?', 282. Brenner laments the over-worthy interpretation of the Song as 'therapeutic antidote for the grim prophetic metaphor'.

${ }^{18} \mathrm{God}$ and the Rhetoric of Sexuality (Philadelphia: Fortress, 1978), especially ch. 5. For her, in the Song, the female body becomes the garden of delights, a paradise regained or at least replaced.
} 


\section{iii What is the Role of Metaphor?}

In the conflict of interpretations the question of what metaphor does is central. In that sense all critics admit that aesthetics has to be taken seriously, that there is something behind the form of words. It may be that Desire as left uncontaminated by divine love or any other construct of superego, society or belief system; or it may be a love in which human and divine erotic agape join in holy alliance. ${ }^{19}$ However, Desire in the accounts of feminist writers is not pure delight or sexual energy: it is a force which drives the female will to power. It may be spoken of as primarily a creative, positive force; as, for example, in Carol

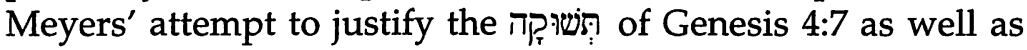
3:16 as given in creation and not a feature of the curse (she also refers to the Song 7:11 where it denotes male desire). ${ }^{20}$

Marcia Falk eschews other critics' flight from literalism (i.e. their reluctance to seek for the precise meaning of each metaphor). Accordingly she delights in the contingency, the particularity of each of the 31 poems each with their own particular tropes or way of combining common ones. ${ }^{21}$ This view of the Song as depicting sensuousness variously and with density of detail is tied to the idea that the Song has a complex aesthetic in which one constantly returns from the abstract to

${ }^{19}$ The distinction between 'Eros and Agape' drawn by Nygren in his eponymous book in the 1930s is by now largely discredited. And yet Barth (in Kirchliche Dogmatik IV, 2, 837ff.; ET 736ff.), while feeling that it had been in its day (i.e. Luther's) a necessary counter to the Medieval teaching which had downplayed the holy otherness of caritas, yet went on to say that eros as an approach to God is hopeless because it tries to play God as an equal partner. More recently the Septuagintal usage of $\dot{\alpha} \gamma \alpha \pi \alpha \dot{\omega} \omega$ has been shown to include the widest semantic field-from lower to higher forms of loving: see J. Barr, 'Words for Love in Biblical Greek', in L.W. Hurst \& N.T. Wright (eds.), The Glory of Christ in the New Testament (Oxford: Oxford University Press, 1987) 3-18. But perhaps Barth was right to suggest that this verb was employed so much precisely in order to banish the connotations of eros-language, that mutual need and desire found the relationship of God and Humanity.

${ }^{20}$ Discovering Eve (Oxford: Oxford University Press, 1988) 111: 'The concept common to this usage and to the sexual nuances of the Canticles and Genesis 3 instances is that of a strong urge of one being for another... Desire is an emotional and/or physical attraction that transcends thought and rationality'.

${ }^{21}$ Love Lyrics from the Bible (Sheffield: Almond Press, 1982) 82ff. 
the concrete. Falk would want to avoid any kind of interpretation that reduces everything to ideologies and singles out R.N. Soulen for criticism on that account. However that is not what Soulen intended. In fact he held that the author was more interested in his hearers' sharing his 'joy, awe and delight': each metaphor appeals to the senses, but in differing ways. ${ }^{22}$ The problem with Falk's insistence on the concrete nature of biblical images is that in such analysis the beauty gets lost in a mire of speculation which is at best bathetic and at worst uninteresting. ${ }^{23}$

Another problem besetting the attempt to gain a vision of what is behind/beyond the text is that when one thing stands for another it soon becomes the other and dies, loses its force. Thus we might fail to see the metaphor in 8:14 because by the time we get there, even on a first reading, 'gazelle' and 'stag' do not make us think in a different way about the beloved-it may be that all it causes us to do is link it with an earlier reference to 2:9.24 Ultimately we might despair of thinking that metaphors do allow us to see anything behind the

22R.N. Soulen, 'The Wasfs of The Song of Songs', JBL 86 (1967) 183-90, at p. 187 \& n. 24, referring to T.S. Eliot on Hamlet, (Selected Essays [London: Faber \& Faber, 1950] 124f.): "The only way of expressing emotion in the form of art is by finding an "objective correlative"; in other words, a set of objects, a situation, a chain of events which shall be the formula of that particular emotion; such that when the external facts, which must terminate in sensory experience, are given, the emotion is immediately evoked'. Thus while Boman (Hebrew Thought Compared to Greek Thought [London: SCM, 1960] 76-84) failed because his interpretation makes images refer to qualities and not to appearances-i.e. they are all a long way of saying 'she is nice'-Soulen here has managed to distance himself from the very position Falk accuses him of holding.

${ }^{23} \mathrm{Cf}$. Falk, Love Lyrics, 83ff. And Falk is not above implying an ideology (Buberian personalism) herself, when she claims (in ch. 3) that love monologues and to a lesser extent dialogues are the purest form of I-Thou expression.

${ }^{24}$ This would appear to be the built-in obsolescence of metaphors which keeps us looking for new ones to help ultimate being break into actuality. Cf. Paul Ricoeur, The Rule of Metaphor (ET; London: Routledge \& Kegan Paul, 1986). Also, E. Jungel, 'Metaphorical Truth', in J. Webster, Theological Essays (ET; Edinburgh: T. \& T. Clark, 1989.) 
literal description, any non-linguistic reality. ${ }^{25}$ I shall return to this in my conclusion.

Landy argues for a mediating position which retreats only half-way from a 'realist' theory of biblical metaphor: his response to the charge that all images of e.g. God in the Bible are merely metaphorical (i.e. literary, non-realist conceits) is that some images and statements are non-metaphorical. ${ }^{26}$ So, YHWH is literally a warrior because he combats Amalekites and Philistines, but only metaphorically a shepherd because he is not concerned with sheep. But, pace Landy, there are nonliteral aspects to YHWH's depiction as a warrior (he himself does not fight but uses natural or supernatural elements to destroy Israel's enemies) and literal aspects to his depiction as shepherd (the primary signification of 'shepherd' is one who cares for, protects and guides). The referent is only half the story when discussing meaning, and the point remains that, especially in biblical discourse, YHWH's activity (shepherding, fighting) is described in metaphorical language which is not too far removed from literal. Such an approximating of the literal and metaphorical has respected defenders in Paul Ricoeur and Janet Soskice. 27

This view of metaphorical realism is the foundation of a Christian hermeneutic which sees all texts as ultimately related to a sufficiently finished revelation of God amongst Israel and in Christ. It was this approach which allowed the Church Fathers to relate difficult, metaphorical texts to a reality that had sufficient detail in it for the variety of metaphors to be plotted against it - that is the coming, life, death, resurrection and second advent of Christ. ${ }^{28}$ For the Fathers, the 'wild nature'

${ }^{25}$ Such would be the view of Jacques Derrida; $c f$. Claudia Camp, 'Metaphor in Feminist Biblical Interpretation: Theoretical Perspectives', Semeia 61 (1993) 3-38. Landy, in his responding article in the volume ('On Metaphor, Play and Nonsense', 219-37) points out that for Derrida it is not that there is nothing there in 'extra-linguistic' reality for texts to point to, only that it is so other as to be unknowable and untraceable by language.

${ }^{26}$ Landy, 'On Metaphor'.

27Ricoeur, The Rule of Metaphor; J.M. Soskice, Metaphor and Religious Language (Oxford: Oxford University Press, 1985).

${ }^{28}$ In the same fashion G.M. Hopkins in The Windhover described the crucifixion of Christ in terms of the natural beauty of the hawk in flight, 
imagery used about the Male Beloved is to do with the attributes and energies of Christ the Lover as one who initiates and acts freely, while the Female Lover as the Church or spiritual soul who responds in imitation (and is herself praised by others) is depicted in images of cultivation and enclosure. Such metaphorical usage does not leave the literal sense far behind in seeking warm currents for its flights of fancy, but remains remains linked to it: the letter is connected with the figurative sense through a mediating concept (e.g. 'apple-tree' is linked to Christ's grace through the concept 'fragrance'). So the common-sense literalism of Brenner and the Tendenz she represents should not be accepted or even resisted halfheartedly.

\section{Christian Theology in and from the Song}

A Christian theology believes that God's love (in creation and redemption) is prior to human love. In fact, the Song itself is not a stranger to this idea. In chapter 8 , verse 6 gives us the philosophical core of the Song.

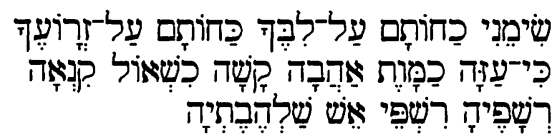

Wear me like a seal on your heart, like a seal on your arm/ For love is strong as death, Ardour as harsh as Sheol/ Its brands the brands of fire ${ }^{29}$

with the observation: 'Brute beauty and valour and act, oh, air, pride, plume, here Buckle! AND the fire that breaks from thee then, a billion times told lovelier, more dangerous, $\mathrm{O}$ my chevalier!' Hopkins' use of metaphor rests self-consciously on a tradition that reaches back to patristic commentaries.

${ }^{29}$ The possibilities of translation are many according to the equivocity of the text. Pope, Song of Songs (Anchor Bible Commentary; New York: Doubleday, 1977) 670 , wants to ignore the word as a gloss on the meaning

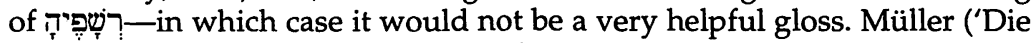
lyrische Reproduktion des Mythischen im Hohenlied', in his collected essays, Mythos-Kerygma-Wahrheit: Gesammelte Aufsätze [Berlin, New York: de Gruyter, 1991] 169) follows Gerleman (Biblische Kommentar, 217) in 
When the ' $\mathrm{I}$ ' fades into the background for the first time in the song, at 8:6f., we are not so much given a thumbnail-sketch cosmology, as a graphic description of Love's extremes to which Love will go. ${ }^{30}$ So the focus of 8:6 is not on what Death, 'Burning', Sheol are but on the qualities of Love-its hardness, the harshness of its passion. ${ }^{31}$ It spreads and has its way quickly and fiercely. Otmar Keel is led to suggest that human love is through its zeal often the unwitting vassal of death; love is fine as a defence, a bulwark, but on the offensive is a deadly force. ${ }^{32}$ However, such a conclusion reads too much into the possibility of love's equivocal or vacillatory nature. How can Love be strong if divided against itself? It is strong, but its relentless movement is all for good.

This is followed by the paradox that although Love is like a flame, it is one that cannot be quenched (v. 7).

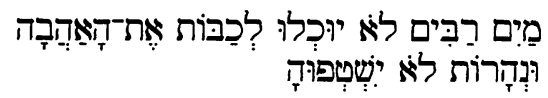

Many waters cannot extinguish love/

Nor streams overflow it.

saying that the element $\pi_{r}$ - has a superlative function: it is 'super fire' or 'lightning'; $C f$. the similar speculation made by D. Winton Thomas about כְְִָּאוֹ in 8,6b: 'A Consideration of Some Unusual Ways of Expressing the Superlative in Hebrew', VT 3 (1953) 209-24. The German commentators line up against the French old guard (Robert, Tournay, Feuillet) who saw the sentiment as a stray piece of prudent wisdom.

30F. Rosenzweig, The Star of Redemption (ET; London: Liffman, 1930). Cf. H. Fisch, Poetry with a Purpose: (Bloomington: Indiana University Press, 1988) ch. 6 ('The Allegorical Imperative'), and especially p. 84, where he argues that the repeated דָ of Song 6:9 gives a transcendent oneness that indicates the woman figure is representative, not of 'universal humanity' but of 'Israel'. In a similar way, 8:6 lays to rest the idea that a game is described here; it is not a comedy or an expression of natural Lustigkeit. (Fisch, Poetry, 81).

31The Syriac translation (unlike the LXX and the Vulgate) of the Hebrew Tִ retains the ambivalence of the term-it is primarily Love's burning which could be either from jealousy or of zeal. The Syriac has problems with the last four Hebrew words, rendering them as 'the burning of its thunderbolt and ושלהביתא. This last item could be understood as one word, a mere transliteration, or possibly as two words (i.e. 'blazing within').

32O. Keel, Das Hohe Lied (Zürich: Theologischer Verlag, 1986) 250f. 
Either this is a poor choice of metaphor, or it is claiming a supernatural quality for love. We are at this moment hearing something about the divine aspect of Love.

Critics tend to stop at this point, but the last 'thought' of $8: 7 \mathrm{c}$ is important for the understanding of the whole and contains resonances not only of the Wisdom Tradition of which the Song is a part but also of the voice of Jesus in the gospelsthe wealth of a person is insignificant compared with Love.

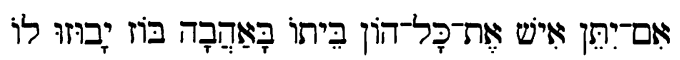

If anyone were to give all his house's wealth for love, despising they would despise him.

The idea in this line is that love makes people go against common sense. But what is this love? Chapter 8 suggests it is not altogether kind-it can hurt as well as heal; it needs to be given some guarantees $(8: 6)$ protected (8:8f.), ordered (8:10-12). It is to be related to the created order and to the will of God as mediated through Wisdom.

So the Song, at 8:7c, as for most of the rest of the book must be talking primarily about human love as a voluntary correspondence to divine love (as alluded to in the mythic language of 8:6 and 8:7ab). Müller feels the Song's romanticism proclaims the divine humanity, that love rises to great heights in the face of finitude; 33 Krinetzki a more pessimistic understanding won from the findings of psychoanalysis, that to love erotically is to fear death, engage with it-you can win the battle, but you cannot in this life be sure to have it under control. ${ }^{34}$ But the statement in 8:7c about one giving away wealth rings less with 'Can't buy me love' than 'Give up all your possessions and follow me!'? One indeed is being asked to image or follow divine Love. The Love of God, by God is presupposed. Genesis 1 precedes Genesis 2. The Song starts in a 'Genesis 2 ' situation and is not about divine love in human

33Müller, Mythos, 170.

${ }^{34}$ G. Krinetzki, Kommentar zum Hohenlied. (Frankfurt-Bern: Lang, 1981) 221; cf. his comments on p. 220 about womb-regression. However the Song is really more about the search of the female psyche. 
disguise. 35 For the Fall demarcates an intrinsic difference between divine and human love, whether or not that distinction existed before the Fall. Nor is the God of the Bible generally one who supplies his own Love for humans to use or participate in; it may be more permissible to think this way when discussing the New Testament, although even there it is hard to find any foundation for assumption Christologies which serve synergistic soteriologies. 36 What we do get in the Song is a portrait of a fresh natural world (its frustration, its 'red-in-tooth-and-claw'-ness removed) whose realities speak of what is Other than human, and reflect the divine possibilities modelled on what is 'given' in Genesis 1.37 The Garden is scorched earth; the Song tells of wilder, more exciting terrain. Wonder, a sense of harmony, pure joy, integration, thankfulness, refreshment into being for others,-these compose the setting in which human love can grow.

\section{Ethics}

It seems no small irony that the line (Song 2:4b) which gave Augustine the most personal satisfaction in inspiring his Christian life and ethical system ('Order love in me') is one which seems either a mistranslation or, as likely, a place where the LXX translator read a text different from today's Masoretic Text (which is 'His banner over me is love'). In other words, it is hard to extract ethics neat from the Song. One has to go via an aesthetic which the Song presents. Having argued that the

\footnotetext{
${ }^{35}$ God may be described in similar terms in Deuteronomy 32:21f., but not in connection with Love: there it is a fire of God's anger which reaches to Sheol, and God is a disappointed Father rather than a lover. A truly biblical-theological account of God's love cannot afford to posit 'jealousy as the other side of God's love' for fear of suggesting a dialectic in God (Webb, 'Love Poem', 98 and nn. 18 \& 19). It is better to see God's wrath as a mode of his Love and vice-versa.

36One thinks of schemas in which Christ is held to be our 'representative', as though he were our elected member of the House of God who embodies all that is best about us.

${ }^{37}$ So the Song's emphasis is more eschatological than creation-focussed. It alludes to a new creation which for all its continuity with the original creation is different from 'the former things'.
} 
text does point to something beyond and that the content of this is the possibilities of human love through imaging divine love, seen most clearly in the world of nature, we need to askwhat kind of ethics?

Francis Landy appears to suggest that transformation can take place through a redefining of our subconscious attitudes by the subtle, pervasive working of metaphor; 38 the Hebrew Scriptures especially offer a freedom from the oppressive dualisms ('Spirit [good]/ matter [bad]') which harm us at an infantile stage. In other words to read the Song is therapy and a better lifestyle, hence morality, necessarily ensues. ${ }^{39}$ There is a jouissance in the Song, which by simply reading or by incantation the reader can share in. It is the fulcrum between the twin drags of Platonic aloofness and pagan over-engagement.

Julia Kristeva would correct Landy's (and most other modern scholars') insistence that the sexual act occurs in the Song; it does not-any jouissance lies beyond the text. 40 Instead there is the two-fold rhythm of going out of oneself and the idea that the Lover is present through language. It is a stern but loving paternal divinity that demands a period of waiting; interim ethics are the ethics of love. ${ }^{41}$ In language that recalls

${ }^{38}$ Landy, 'On Metaphor', 221: 'Metaphor is the vehicle, the venture, of metamorphosis, transferring the pliant woman, the commodity of social exchange, to the domain of hardness.' Concomitant with this is the sense that in the Song the face of lovers becomes revealed continually in their bodies which amounts to a type of incarnation. Landy acknowledges his debt to Luce Irigiray-see "The Fecundity of the Caress: A Reading of Levinas, Totality and Infinity', in R. Cohen (ed.), Face to Face with Levinas (Albany: State University of New York Press, 1986) 231-56.

${ }^{39}$ The two Platonic images which harm us are that of the cave with its suggestion we should all flee maternal shelter and the idea of eros as something which flies away from the concerns of the earth. The Song subverts a flight from the feminine.

40J. Kristeva, Tales of Love (ET; New York: Columbia University Press, 1987) $96 f$.

${ }^{41} C f$. James Houston's suggestion (in a study of the Song in Western Spirituality which also relates it to New Testament eschatology) that delay of God's parousia is what drives us to prayer, realisation of sin, and thus inner change (The Heart's Desire, Oxford-Batavia-Sydney: Lion, 1992) 198. Houston (205) observes that the Song's ethical model is that of an 
the medieval Rabbinic concept of the Torah as God's incarnate body, 42 she writes that the Wholly Other intoxicates us with the presence of his Name through select words: "The sensitive and the significant, the body and the name, are thus not only placed on the same level but fused in the same logic of undecidable infinitization, semantic polyvalence brewed by the state of love.' 43

For Rosenzweig the Song is the last stop on the journey of revelation; ethics only really begins thereafter, with the garden of the Song and God's love for our individual souls behind it:

'The beloved must know herself, as it were, thrown solely upon its own resources, unloved, with all its love not being loved, but eternally loving...only in her heart of hearts may she hold to that dictum of the ancients... "As He loves you, so shall you love."'44

It is not easy to translate love into a public sphere when it is so much a privately personal affair. But in ethics God/the Good/That Which is Otherwise than Being is a force which helps me to think of the other person as that person, rather than for that person. 45

Now surely this is close to what sexual ethics is all about. It involves thinking of another person as essentially unrelated to me, one for whom I have adopted a responsibility. It means seeing the face of the Divine Other in the one who is vulnerable. It needs prayer and invocation of friends and spiritual power; it has to be a public privacy. It sees bodies as a reminder of all that is pure gift and makes us belong. It requires natural desire and mutual companionship to aim for the

(equilateral?) triangle of which commitment, passion and intimacy form the three sides.

${ }^{42}$ This is a dominant theme in the recent observations of $\mathrm{J}$. Neusner on medieval Rabbinism.

43J. Kristeva, Tales, 90. Elsewhere, Kristeva has described this 'Other' as 'pure signifier' (i.e. nothing can be signified of 'him'); see Desire in Language (ET; New York: Columbia University Press, 1987) 17.

44The Star of Redemption, 274.

${ }^{45} \mathrm{C}$. Emmanuel Levinas, Otherwise than Being (ET; Dordrecht/Boston/ London: Kluwer, 1991). 
covenant perfection of God's love. The Song describes and affirms what is natural so that we can understand what The Word of God assumed (Bonhoeffer). ${ }^{46}$ And yet this is precisely where Christian revelation goes further; the practical aid we need, when even understanding is insufficient, points us from this insight of Bonhoeffer's to another one which balances and complements it-that we only truly love someone when we love them in Christ. ${ }^{47}$ Thus perhaps the open circuit pictured by Rosenzweig can be closed by Christ.

Now for Lüthi the answer is that we should refuse beauty any significance unless charm, wit and humour are mixed in. We should not exaggerate the seriousness of sex,48 and can laugh approvingly at the games of secrecy young people have to play ( $c f$. the Song's descriptions of nocturnal affairs in secret). ${ }^{49}$ Sex is so ridiculously ordinary that it (a) needs no extraneous regulations, (b) qualifies as the stuff of sacrament; the human relationship thus mirrors God's love for

46D. Bonhoeffer, Widerstand und Ergebung: Briefe und Aufzeichnungen aus der Haft (München: Kaiser, 1977) 345 (= [ET; London: SCM, 1953] 315). However, note the statement of the condition for eros at p. 303 (ET): 'Where the cantus firmus [viz., agape] is clear and plain, the counterpoint [viz., eros] can be developed to its limits.'

47 idem, Gemeinsames Leben (München: Kaiser, 1987) 18: 'Christliche Gemeinschaft weißt Gemeinschaft durch Jesus Christus und in Jesus Christus...Wir gehören einander allein durch und in Jesus Christus'.

${ }^{48}$ Thus he minimizes Song 8:6 as being to do with the 'little death' of parting. For him, the eros-thanatos connection does not make eros tragic, but rather only roots it in matter and finite existence.

${ }^{49}$ 'Schönheit ist Schönheit auf Grund von Reizwirkungen.' There is nothing superior about physical beauty; it does not reflect the soul or a metaphysical truth which we should be in awe of. This echoes Tillich: $c f$. Systematic Theology (London: SCM, 1968) Vol. III, 69ff. Even the idea that the possibility of children inherent in the sexual act demands the safetynet of marriage covenant (so Gollwitzer, Das Hohe Lied, 53) has been dropped as an embarrassment. The preoccupation of this tradition of ethics with negating the negatives (e.g., that any rules have to help love to last) forgets that love manages its own course without reference to external encouragements. It is how sexual love fits with the rest of life (friendship, vocation, politics) that requires assistance external to the loveexperience. Even were the 'nocturnal' and 'clandestine' character of the Song's lovers' trysts proven, this would tell us little that was conclusive about the 'physicality' let alone the 'comedy' of their liaison. 
his people. Sexual love is thus important because it is material. ${ }^{50}$ In Lüthi's view, sexuality becomes a part of nature which needs humanisation.

Yet this is totally the opposite of the Song's thrust-that creation already has a transparency, a window on the divine which means that humans need to look at and learn from it. The priority is not that we liberate or humanise Nature, but that we ourselves be liberated. ${ }^{51}$ To give a biblical parallel, it is we whom creation is waiting on, not to bring redemption, but that redemption might happen; we are the guest the party cannot start without, but hardly the Host. As we look at the imagery in the Song, it points us away from ourselves to a vision that there is more to existence than our lives. So too, in our lives we move towards a biblical (yet authentically modern) morality which goes beyond sexuality by seeing our bodies as intricately and essentially parts of creation which are waiting for our wills to catch up and stop misusing them. It is no coincidence that the Song ends with the encouragement 'Make haste my beloved, and be like a gazelle or a young stag upon the mountain of spices.' The metaphor has taken over from any reference to the parts of the human body; our whole selves are caught up in the identification with the ascending animals. Thus we are helped to view sexual experience as something which in presenting our corporeality to us reminds us of our belonging to the created order and so summons us out of ourselves. Of course, Christian Ethics in a pictorial message which is congruous with that of the Song and fulfils it, points us towards the consummation of a relationship with a divine-human Lover in heaven (Rev. 21:1-4). But precisely because that is a further chapter in the same story, the Church Fathers were not wrong to read it in tandem with the poetry of the Song.

${ }^{50}$ Lüthi even argues that the sinner woman in Lk. 7:47a was forgiven much because she had loved much; this exegesis ignores the parallelism of v. 47b: 'but he who is forgiven little, loves little.'

51So I would take issue with Paul Avis, Eros and the Sacred (London: SPCK, 1989) who envisages God's love as being at least as much eros ('the love that longs to bring to perfection the innate dignity and worth of its objects and seeks a like response, leading to communion', p. 136) as it is agape. That image (or likeness) is not there for God to admire but for him laboriously to restore throughout our lifetimes. 